\title{
Correction to "Characterization of nutrients in the atmospheric wet and dry deposition observed at the two monitoring sites over Yellow Sea and East China Sea"
}

\author{
Guosen Zhang • Jing Zhang • Sumei Liu
}

Received: 25 December 2007 / Accepted: 9 January 2008 / Published online: 6 February 2008

(C) Springer Science + Business Media B.V. 2008

\section{Erratum to: J Atmos Chem DOI 10.1007/s10874-007-9060-3}

In the paper "Characterization of nutrients in the atmospheric wet and dry deposition observed at the two monitoring sites over Yellow Sea and East China Sea" by Guosen Zhang, Jing Zhang and Sumei Liu (Journal of Atmospheric Chemistry, 2007, 57: 41-57), errors were introduced into the Table 6. The corrected table is as follows:

Table 6 Measured fluxes in the atmospheric deposition of nutrients $\left(\mu \mathrm{mol} / \mathrm{m}^{2} \cdot \mathrm{yr}\right)$

\begin{tabular}{llllll}
\hline Site & Deposition Flux & $\mathrm{NO}_{3}^{-}+\mathrm{NO}_{2}^{-}$ & $\mathrm{NH}_{4}^{+}$ & $\mathrm{PO}_{4}^{3-}$ & $\mathrm{SiO}_{3}^{2-}$ \\
\hline Yellow Sea & Dry & 9,780 & 9,300 & 115 & 54.2 \\
& Wet & 24,600 & 33,500 & 489 & 1,370 \\
\multirow{3}{*}{ East China Sea } & Total & 34,380 & 42,800 & 604 & 1,424 \\
& Dry & 7,190 & 7,020 & 49.2 & 22.6 \\
& Wet & 21,500 & 32,700 & 65.2 & 1,950 \\
& Total & 28,690 & 39,720 & 114 & 1,973 \\
\hline
\end{tabular}

The online version of the original article can be found at doi:10.1007/s10874-007-9060-3.

G. Zhang $\cdot$ J. Zhang $\cdot$ S. Liu

College of Chemistry and Chemical Engineering, Ocean University of China, 5 Yushan Road,

Qingdao 266003, People's Republic of China

G. Zhang $(\bowtie) \cdot J$. Zhang

State Key Laboratory of Estuarine and Coastal Research, East China Normal University,

3663 Zhongshan North Road, Shanghai 200062, People's Republic of China

e-mail: gszhang@sklec.ecnu.edu.cn 